\title{
KARAKTERISTIK ALIRAN PADA BELOKAN SALURAN TERBUKA
}

\author{
ADY PURNAMA ${ }^{1}$ \& ENI NURAINI ${ }^{2}$ \\ ${ }^{1,2}$ Dosen Program Studi Teknik Sipil Fakultas Teknik Universitas Samawa Sumbawa Besar
}

\begin{abstract}
Abstrak
Studi tentang Saluran berbelok cukup penting, karena saluran berbelok mempunyai karakteristik yang unik dengan tingkat rawan yang cukup tinggi terhadap daya rusak air bila dibandingkan dengan saluran lurus. Melalui penelitian ini diharapkan dapat memberikan informasi tambahan pada pemanfaatan air bersedimen yang lebih efisien yakni mengenai wilayah mana akumulasi partikel-partikel sedimen suspensi berada dan juga sebagai referensi untuk pendeteksian awal terjadinya banjir serta sebagai referensi dalam menganalisa distribusi kecepatan dan sedimen pada belokan saluran yang bervariatif atau saluran berbentuk kelokan berlanjut (meandering) atau kelokan tunggal (curvature bend profile). Dari hasil analisis terhadap pengukuran kecepatan aliran dan konsentrasi sedimen suspensi yang dilakukan pada tiga lokasi dengan sudut dan jari-jari belokan yang bervariasi, menunjukkan bahwa untuk trend kecepatan minimum terjadi di dekat dasar dan bertambah besar ke arah permukaan aliran. Kecepatan aliran mengalami percepatan dan perlambatan ketika melalui belokan, dimana kecepatan aliran meningkat di sisi dalam belokan (inner bank) ketika melewati awal belokan dan kecepatan menurun saat melewati akhir belokan dan sebaliknya kecepatan menurun di sisi luar belokan (outer bank) ketika melewati awal belokan dan mengalami peningkatan di sisi dalam belokan saat melewati akhir belokan. Adapun konsentrasi sedimen suspensi mempunyai trend yang hampir sama untuk seluruh tampang, yaitu konsentrasi sedimen suspensi meningkat ke arah dasar saluran dan mengalami penurunan ke arah permukaan air dengan trend distribusinya semakin tegak dengan nilai yang semakin seragam ke arah permukaan air. Pada arah transversal, konsentrasi sedimen suspensi cenderung meningkat ke arah sisi dalam belokan ketika melewati awal belokan, lalu menurun ke arah sisi dalam belokan saat melewati pertengahan belokan dan kembali meningkat ke arah sisi dalam belokan saat melewati akhir belokan yang mengakibatkan terjadinya deposition di sisi dalam belokan (inner bank) dan erosion di sisi luar belokan (outer bank) pada dasar saluran. Untuk analisis konsentrasi sedimen suspensi hasil pengukuran lapangan yang dibandingkan dengan analisis dari persamaan Rouse dan persamaan Tanaka-Sugimoto menunjukkan bahwa cukup dapat memprediksi data pengukuran konsentrasi sedimen suspensi pada belokan, meskipun sudut dan jari-jari belokan bervariasi. Data hasil pengukuran sedimen suspensi nilainya mendekati data hasil analisis Rouse dan Tanaka-Sugimoto. Adapun hasil analisis Tanaka-Sugimoto bisa memberikan hasil lebih baik dari analisis Rouse.
\end{abstract}

Keywords: konsentrasi sedimen suspensi, kecepatan, saluran berbelok, metode Rouse, metode Tanaka-Sugimoto.

\section{PENDAHULUAN}

Memprediksi perilaku aliran pada saluran terbuka di belokan cukup penting, karena saluran tidak selamanya lurus dan akan tetap ada belokan di sepanjang saluran sehingga alur aliran yang melalui saluran akan terpengaruh oleh belokan tersebut. Seperti halnya sungai yang mempunyai bentuk fisik yang bervariatif sehingga pola alirannya sangat kompleks dengan karakteristik yang khusus. Secara umum, faktor yang mempengaruhi aliran pada belokan adalah gaya sentrifugal akibat kelengkungan aliran, ketidakseragaman kecepatan tampang vertikal, tekanan pada potongan, dan gradien tekanan arah radial yang disebabkan oleh kemiringan lateral permukaan air (Chow 1959). Hal yang tak kalah penting dari perilaku kecepatan aliran pada belokan adalah perilaku sedimen (transport sedimen). Transpor sedimen yang terjadi pada saluran terbuka, sungai dan waduk merupakan peristiwa yang sangat kompleks. Proses terjadinya pendangkalan sungai sebagai akibat 
dari proses erosi (scouring) pada bagian hulu sungai, yang mengakibatkan terjadinya angkutan sedimen ke hilir. Aliran air yang mengandung sedimen akan mengendapkan terlebih dahulu butiran kasar (bed load) dibandingkan dengan butiran halus (suspended load) yang akan terus melayang mengikuti aliran air. Kondisi seperti inilah yang kadang menjadi permasalahan dalam pemanfaatan air sungai. Oleh karena itu, pengetahuan mengenai kuantitas dan karakteristik sedimen suspensi sangatlah penting dalam pengembangan sumber daya air (water resources).

Berdasarkan dari uraian di atas, cukup layak dilakukan penelitian terkait distribusi sedimen suspensi pada belokan saluran dengan melakukan pengukuran konsentrasi sedimen suspensi dan kecepatan aliran. Maka dari itu, dalam penelitian ini akan membahas distribusi sedimen suspensi di belokan pada saluran terbuka.

\section{KAJIAN PUSTAKA}

\section{a. Penelitian Distribusi Kecepatan Terdahulu}

Hasil eksperimen oleh Rozovskii, I. L. (1957, dalam Nugroho, B, 2012) pada pengukuran kecepatan di saluran menikung $180^{\circ}$ dengan dasar halus menunjukkan perubahan distribusi kecepatan pada tikungan. Pada awal tikungan kecepatan meningkat disisi dalam tikungan dan menurun disisi luar tikungan, kondisi sebaliknya terjadi di akhir tikungan dimana kecepatan maksimum terjadi di sisi luar tikungan dan minimum terjadi pada sisi dalam tikungan. Hal tersebut terjadi karena aliran di awal tikungan memiliki garis aliran yang dominan lurus, sebaliknya yang terjadi pada akhir tikungan dimana garis aliran sudah mengikuti bentuk tikungan adalah ketika pada saat saluran sudah kembali lurus, garis aliran masih mengarah ke luar tikungan.

Penelitian aliran menikung lainnya dengan dasar tidak rata (natural) dilakukan oleh Blanckaert, K (2001) menggunakan alat ukur ADVP (Acoustic Doppler Velocity Profiler) yang dapat mengukur kecepatan tiga arah (longitudinal, transversal dan vertikal) pada tampang secara bersamaan dengan grid yang diatur.

\section{b. Penelitian Distribusi Sedimen Terdahulu}

Kironoto, Lutjito dan Nugraha (2002)

telah melakukan pengukuran konsentrasi sedimen suspensi di laboratorium PAU Universitas Gadjah Mada. Penelitiannya menunjukkan bahwa rumus Rouse dan TanakaSugimoto Persamaan Rouse dan persamaan Tanaka-Sugimoto masih dapat memprediksi data pengukuran distribusi konsentrasi sedimen suspensi relatif cukup baik, baik untuk aliran seragam, aliran diperlambat maupun untuk aliran dipercepat. Hasil penelitian dapat di lihat pada gambar 1 .

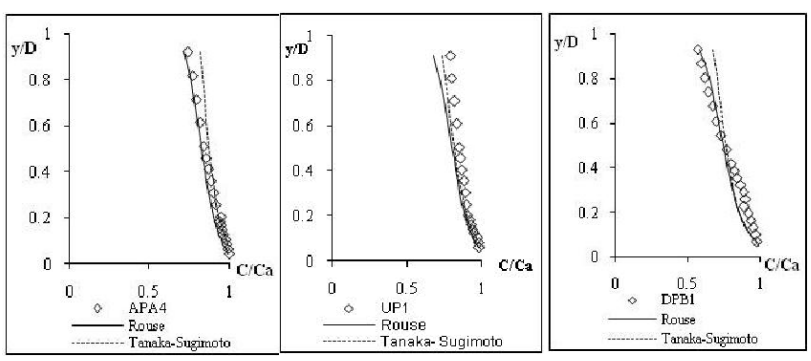

Gambar 1 Distribusi konsentrasi sedimen suspensi hasil pengukuran dibandingkan dengan persamaan Rouse dan persamaan Tanaka-Sugimoto, untuk aliran seragam, aliran diperlambat dan aliran dipercepat (Kironoto, Lutjito dan Nugraha, 2002)

Zainuddin dan Kironoto (2003) melakukan pengukuran distribusi konsentrasi sedimen suspensi pada saluran terbuka di laboratorium, dengan menggunakan peralatan optical silt measuring instruments tipe Foslim probe-set. Hasil yang diperoleh menunjukkan kesesuaian yang baik dengan hasil pengukuran yang diperoleh berdasarkan pengambilan sampel konvensional (dengan botol sampel) dan hasilnya juga menunjukkan kesesuaian yang baik dengan teori-teori di literatur.

Kironoto, dkk (2004) melakukan pengukuran distribusi konsentrasi sedimen suspensi pada saluran terbuka di laboratorium, hasil yang didapatkan bahwa adanya korelasi antara lokasi pengambilan sampel sedimen suspensi (dan debit aliran) dengan debit sedimen suspensi rata-rata tampang. Diketahui pula bahwa debit sedimen suspensi yang ditentukan berdasarkan data sampel sedimen suspensi di tepi saluran akan memberikan prediksi debit sedimen suspensi yang terlalu kecil, sebaliknya bila didasarkan pada sampel sedimen di tengah akan memberikan prediksi yang terlalu besar. Sehubungan dengan itu, telah diusulkan suatu faktor koreksi, bilamana 
pengambilan sampel sedimen suspensi tetap dilakukan pada titik-titik tertentu pada arah transversal. Lokasi titik pengambilan sampel sedimen suspensi arah transversal yang memberikan nilai faktor koreksi 1 , terjadi pada posisi $\mathrm{z}=0,195 \mathrm{~B} \approx 0,2 \mathrm{~B}$, dengan $\mathrm{B}$ adalah lebar saluran.

Kironoto dan Ikhsan (2005) melakukan pengukuran distribusi konsentrasi sedimen suspensi di lapangan, yaitu pada Saluran Irigasi Mataram, Yogyakarta, dengan menggunakan peralatan optical silt measuring instruments tipe Opcon probe-set. Hasil yang diperoleh juga menunjukkan kesesuaian yang baik dengan hasil pengukuran yang didasarkan pada pengambilan sampel secara konvensional (dengan botol sampel) dan sesuai dengan teori-teori di literatur.

\section{c. Distribusi Kecepatan Aliran}

Distribusi kecepatan aliran dalam saluran biasanya sangat bervariasi dari satu titik ke titik lainnya (tidak merata) pada seluruh tampang saluran terbuka. Hal ini dapat dijelaskan dengan konsep kekentalan fluida dan kekasaran saluran dimana perbedaan tersebut disebabkan adanya tegangan geser di dinding dan dasar saluran. Dari beberapa penelitian, distribusi kecepatan pada saluran terbuka dibagi menjadi dua wilayah yaitu inner region dan outer region, dapat dilihat pada Gambar 2, dimana aliran pada inner region dipengaruhi langsung oleh kekasaran dasar/dinding dan aliran pada outer region dipengaruhi secara tidak langsung melalui tegangan geser dasar.

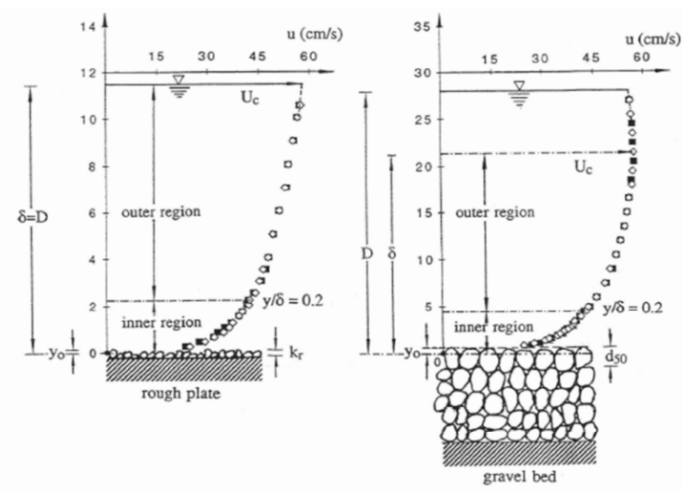

Gambar 2 Pembagian inner region dan outer region pada aliran dasar kasar (Kironoto, 1993)

(1) Inner Region

Tegangan gesek pada aliran turbulen diakibatkan oleh tegangan gesek laminer (akibat viskositas) dan turbulen/Reynolds (akibat fluktuasi turbulen). Tegangan gesek laminer dominan di dekat dasar pada kedalaman lapis batas laminer yang dipengaruhi kekasaran dasar secara langsung, sedangkan tegangan gesek turbulen tidak dipengaruhi secara langsung dengan kekasaran dasar melainkan dipengaruhi tegangan gesek dasar.

Untuk aliran seragam, distribusi arah vertikal dari tegangan Reynolds arah longitudinal $\left(-\overline{u^{\prime} w^{\prime}}\right)$ dapat ditulis sebagai berikut :

$$
\frac{\tau_{0}}{\rho} \equiv-\overline{u^{\prime} w^{\prime}}=u_{*}^{2}\left(1-\frac{z}{h}\right)
$$

dimana, $\tau_{0}$ adalah tegangan geser total, - $\rho \overline{u^{\prime} w^{\prime}}$ adalah tegangan geser Reynolds, dan $u_{*}$ adalah kecepatan geser (Yulistiyanto, 1997). Tegangan Reynolds, $-\overline{u^{\prime} w^{\prime}}$ semakin besar mendekati dasar dan berangsur mengecil pada permukaan air (Kironoto, 1993).

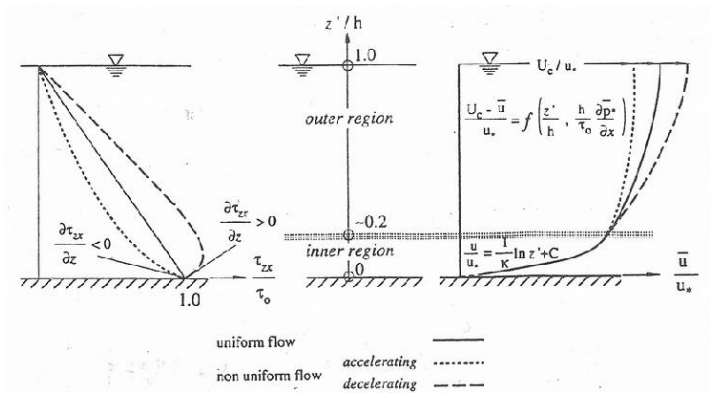

Gambar 3 Skema Distribusi Tegangan Geser,

$-\overline{u^{\prime} w^{\prime}}$ dan Kecepatan Longitudinal, $u$, pada

Kondisi Tak-Seragam (Graf \& Altinakar, 1998 dalam Sangging, P.Y.B, 2013)

Dari profil tegangan Reynolds $-\overline{u^{\prime} w^{\prime}}$ dapat diperoleh nilai dari kuadrat kecepatan geser, $u_{*}^{2}$, dengan cara fitting curve dari distribusi data tersebut mengikuti persamaan (6) pada $z=0$. Sedangkan komponen tegangan geser Reynolds arah transversal, $-\overline{v^{\prime} w^{\prime}}$, jauh lebih kecil dibandingkan arah longitudinal (Yulistiyanto, 1997).

Adapun untuk menghitung kecepatan titik $U_{y}$, bisa juga didekati dengan formula lainnya yakni Hukum Distribusi Kecepatan Universal Prandtl-Von Karman dengan menggunakan metode Clauser yang diperoleh dari 
pengukuran profil kecepatan dengan persamaan distribusi kecepatan logaritmik (Kironoto, 1993), yang berlaku untuk data pengukuran daerah inner region $(y / D \leq 0,2$ atau $y / \delta \leq 0,2$ ) sebagai berikut :

$$
\begin{aligned}
& \frac{U_{y}}{U_{*}}=\frac{1}{\kappa} \ln \left(\frac{y}{k_{s}}\right)+B r \\
& U_{y}=\frac{U_{*}}{\kappa} \ln \frac{y}{k_{s}}+B r \cdot U_{*}
\end{aligned}
$$

Terlihat bahwa Persamaan (2) merupakan persamaan logaritmik dengan $U_{y}$ sebagai variabel yang akan dihitung. Kemudian Persamaan (2) di atas dijabarkan menjadi Persamaan (3) berikut.

$$
U_{y}=\frac{U_{*}}{\kappa} \ln y-\frac{U_{*}}{\kappa} \ln k_{s}+B r . U_{*}
$$

dengan asumsi, $U_{y}$, kecepatan pada suatu titik yang berjarak y dari dasar $(\mathrm{m} / \mathrm{s}), U_{*}$, kecepatan gesek $(\mathrm{m} / \mathrm{s}), y$, ketinggian titik yang ditinjau dari dasar saluran terbuka $(m), k$, konstanta Von Karman (bernilai 0,4$), k_{s}$, tinggi kekasaran menurut Nikuradse $(\mathrm{m}), \mathrm{Br}$, konstanta integrasi numerik (log law) dan yo = $0,2 k_{s}$.

Sehingga untuk mendapatkan persamaan yaitu dengan memplotkan kecepatan titik $\left(U_{y}\right)$ hasil pengukuran sebagai ordinat dan In $y$ sebagai absisnya. Kemudian didapat persamaan logaritmik profil distribusi kecepatan.

\section{(2) Outer Region}

Pada outer region profil kecepatan menyimpang dari persamaan logaritmik. Disini berlaku distribusi kecepatan Coles, yang juga berlaku untuk inner region.

$$
\frac{U_{C}-u}{u_{*}}=-\frac{1}{\kappa} \ln \left(\frac{z}{\delta}\right)+\frac{2 \prod}{\kappa} \cos ^{2}\left(\frac{\pi z}{2 \delta}\right)
$$

dengan asumsi, $U_{C}$, kecepatan maksimum, $\delta$, kedalaman titik dimana terjadi kecepatan maksimum $\left(H_{c}\right)$ dan $\Pi$, parameter wake Coles $(\Pi=-0,03$ untuk $B / D \approx 2 \& \Pi=0,09$ untuk $B / D$ $>5$ ).

\section{d. Aliran Pada Belokan}

Belokan atau tikungan pada saluran terbuka menyebabkan perubahan arah aliran. Jika debit (Q), kecepatan rerata penampang (U) dan luas penampang basah $(A)$, konstan sepanjang belokan, maka faktor kedalaman $(h)$ pada setiap bagian atau titik pengukuran mempengaruhi besar super-elevasi muka air ( $\Delta z$ ) pada sisi luar tikungan (outer bank). Kecepatan maksimum terjadi pada lingkar dalam tikungan (inner bank). Lihat Gambar 4 (Graf \& Altinakar, 1998).

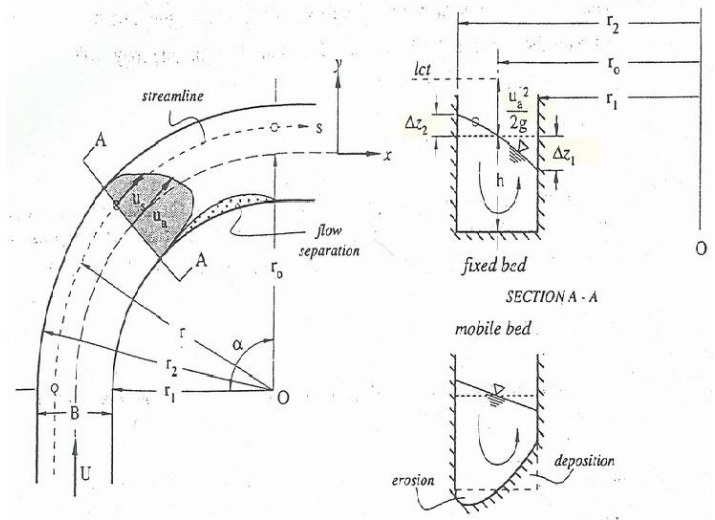

Gambar 4 Skema Aliran pada Tikungan (Graf \& Altinakar, 1998 dalam Sangging, P.Y.B, 2013)

Pada tikungan, aliran streamlines tidak lagi paralel dan menjadi aliran 3D. Kompleksitas dari aliran ini dapat didekati dengan salah satu metode yang diusulkan oleh Kozeny (1953), yaitu dengan pendekatan kemiringan garis energy, $S_{e}$ berikut :

$$
S_{e}=\frac{h_{r}^{c}}{L_{c}}=\lambda u_{s}^{2}
$$

dengan asumsi $h_{r}^{c}$ adalah head loss, $s$ adalah notifikasi streamline, $\lambda$ adalah factor of proportionality, dan $L_{c}=\alpha r$ adalah panjang tikungan; dimana $\alpha$ adalah sudut tikungan, dan $r$ adalah radius tikungan. Maka persamaan tersebut dapat ditulis sebagai berikut :

$$
u_{s}=\sqrt{\frac{h_{r}^{c}}{\lambda \alpha}} \cdot \sqrt{\frac{1}{r}}=\frac{\kappa}{\sqrt{r}}
$$

dengan $r=r_{o}$, dan $u_{s}=u_{a} \equiv U$, ini menyatakan bahwa kecepatan axial, $u_{a}$ identik dengan kecepatan rerata, $U$ pada suatu penampang melintang. Dan jika $r_{1}$ dan $r_{2}$ adalah radius sisi dalam dan sisi luar, maka dapat dinyatakan sebagai berikut :

$$
u_{1}=u_{a} \sqrt{r_{o} / r_{1}} \text { dan } u_{2}=u_{a} \sqrt{r_{o} / r_{2}}
$$

dimana lebar saluran, $B=r_{2}-r_{1}$, maka : 


$$
\Delta z=\frac{B r_{o}}{r_{1} r_{2}} \cdot \frac{U^{2}}{2 g}
$$

jika $B$ lebih kecil dibandingkan radius tikungan, maka penyederhanaan persamaan (9) menjadi :

$$
\Delta z=\frac{B}{r_{o}} \cdot \frac{U^{2}}{2 g}
$$

maka lengkung muka air melintang dengan kondisi fixed bed dapat didekati dengan persamaan berikut :

$$
\Delta z_{2}=\frac{U^{2}}{2 g}\left(1-\frac{r_{o}}{r_{2}}\right) \text { dan } \Delta z_{1}=\frac{U^{2}}{2 g}\left(\frac{r_{o}}{r_{1}}-1\right)
$$

Jika material penyusun dasar saluran adalah material tererosi, maka pada sisi luar (outer bank) akan terjadi erosi, dan deposisi akan terjadi pada sisi dalam tikungan (inner bank).

\section{e. Konsentrasi Sedimen Suspensi}

Pada kondisi tertentu partikel-partikel bed load bergerak dari dasar, demikian pula halnya dengan material-material berbutir halus yang berada dalam aliran yang di transport dalam bentuk suspensi, partikel dengan butiran sangat kecil pun mempunyai berat (gaya berat/gravitasi) dan dalam aliran ada gaya yang menggerakkannya, gerakan ini diakibatkan oleh adanya turbulensi atau fluktuasi aliran, sehingga bila gaya berat partikel lebih besar dari gaya yang menggerakkannya, maka partikel cenderung untuk mengendap pada kondisi tertentu.

Partikel sedimen dikatakan bergerak secara melayang (suspended load) bilamana partikel tersebut bergerak tanpa menyentuh dasar saluran. Karena adanya pengaruh gaya berat, partikel tersebut cenderung untuk mengendap. Kecenderungan untuk mengendap ini akan dilawan oleh gerakan partikel zat cair, yaitu komponen fluktuasi kecepatan dari aliran turbulen. Dengan kata lain kondisi aliran yang ada akan menentukan apakah suatu fraksi sedimen akan bergerak sebagai sedimen suspensi atau bukan.

Distribusi konsentrasi sedimen suspensi dapat diperoleh dari persamaan difusi untuk sedimen suspensi :

$$
w_{s} C+\varepsilon_{s} \frac{\partial C}{\partial y}=0
$$

dimana $C$ adalah consentrasi sedimen suspensi, $w_{s}$, kecepatan endap partikel sedimen, $\varepsilon_{s}$, difusi turbulen (eddy diffusion) dan $y$ kedalaman aliran.

Untuk parameter gradien tekanan baik pada non-uniform flow ataupun uniform flow dapat didefinisikan sebagai berikut:

$$
\beta_{n}=\frac{D}{\tau_{0}} \frac{\partial p^{*}}{\partial x}=\frac{D}{\tau_{0}}\left[\gamma\left(-S_{0}+\frac{\partial D}{\partial x}\right)\right]
$$

dengan $\beta_{n}$ sebagai parameter gradien tekanan, $D$, kedalaman aliran, $S_{0}$, sebagai kemiringan dasar, $\tau_{0}$ tegangan geser dasar dan $\gamma$ berat volume.

Integral dari persamaan (13) memberikan persamaan:

$$
\ln \frac{C}{C_{a}}=-\int_{a}^{y} \frac{w_{s}}{\varepsilon_{s}} d y
$$

dimana $C_{a}$ adalah konsentrasi referensi dari sedimen suspensi pada jarak $y=a$ dari dasar, seperti ditunjukkan pada Gambar 5.

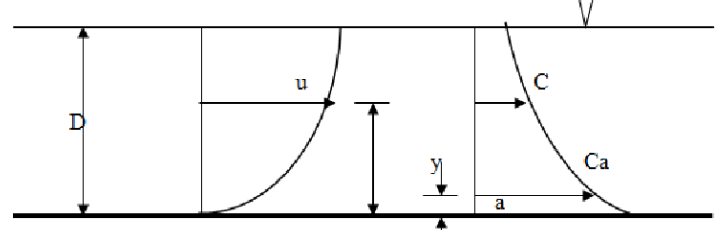

Gambar 5 Profil kecepatan dan konsentrasi sedimen suspensi pada tampang saluran

$$
\text { (Lutjito, 2002) }
$$

Sebagai pendekatan dapat di asumsikan $\mathrm{w}_{s}$ dan $\varepsilon_{s}$ dipertahankan konstan terhadap y sehingga:

$\ln \frac{C}{C_{a}}=-\frac{w_{s}}{\varepsilon_{s}}(y-a)$ atau $\frac{C}{C_{a}}=\exp \left[-\frac{w_{s}}{\varepsilon_{s}}(y-a)\right]$

\section{f. Distribusi Sedimen Suspensi}

Rouse memodifikasi bahwa $\varepsilon_{s}=b . \varepsilon_{s}$, dengan $B=1$ untuk sedimen halus, maka $\varepsilon_{m}=$ $\varepsilon_{s}$. Koefisien transfer momentum $\varepsilon_{m}$ pada teori panjang campur (mixing length) oleh Prandtl sebagai berikut:

$$
\varepsilon_{m}=\frac{\tau}{\rho\left(\frac{d u}{d y}\right)}
$$

Sedangkan tegangan geser bervariasi secara linier terhadap jarak dari dasarnya.

$$
\tau=\tau_{0}\left(1-\frac{y}{D}\right)
$$


dengan $\tau_{0}=\gamma D S$

Substitusi persamaan

(17) ke dalam persamaan (16) diperoleh :

$$
\varepsilon_{m}=\frac{\tau_{0}}{\rho}\left(\frac{D-y}{D}\right) \frac{1}{d u}
$$

Untuk gradien kecepatan $d u / d y$ dapat dievaluasi dengan berdasarkan pada persamaan distribusi kecepatan Prandtl - Von Karman, yaitu:

$$
\frac{d u}{d y}=\frac{u_{*}}{\kappa} \frac{1}{y}
$$

dimana $K$ adalah konstanta universal dari Von Karman, yang nilainya $k=0.4$ untuk air jernih. Dengan memasukkan persamaan (19) kedalam persamaan (18) dapat diperoleh:

$$
\varepsilon_{m}=\varepsilon_{s}=u_{*} \kappa y\left(\frac{D-y}{D}\right)
$$

Dengan mengambil $\varepsilon_{m}=\varepsilon_{s}$, dan substitusikan persamaan (20) kedalam persamaan (14)

$$
\ln \frac{C}{C_{a}}=-\frac{w_{s}}{u_{*} \kappa} \int_{a}^{y} \frac{D d y}{y(D-y)}
$$

dengan mengambil nilai:

$$
z=\frac{w_{s}}{\kappa u_{*}}
$$

Persamaan ini dipublikasikan oleh Rouse, sehingga $z$ sering disebut sebagai parameter Rouse (Rouse number).

$$
\begin{aligned}
& \ln \frac{C}{C_{a}}=z \int_{a}^{y} \frac{D d y}{y(D-y)} \\
& \frac{C}{C_{a}}=\left[\frac{D-y}{y} \frac{a}{D-a}\right]^{z}
\end{aligned}
$$

dengan $C$ sebagai konsentrasi sedimen pada suatu titik berjarak $y$ dari dasar referensi; $C_{a}$, konsentrasi referensi yang berjarak $a$ dari titik referensi; $D$, kedalaman aliran dan $z$ sama dengan parameter Rouse.

Distribusi konsentrasi sedimen suspensi menurut persamaan (24) diperlihatkan pada Gambar 6, ditunjukkan bahwa konsentrasi sedimen suspensi semakin jauh dari dasar konsentrasinya semakin berkurang.

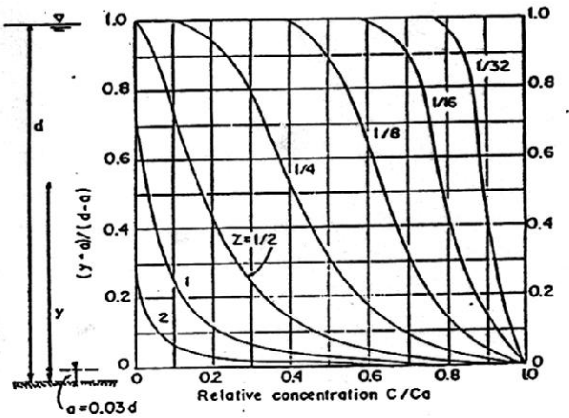

Gambar 6 Distribusi konsentrasi sedimen suspensi menurut Rouse (Vanoni, 1977)

Tanaka dan Sugimoto (1958, dalam Garde, 1977) mengusulkan suatu persamaan eksponensial untuk distribusi sedimen. Dikemukakan bahwa hukum distribusi kecepatan logaritmik Karman-Prandtl yang berasumsi bahwa $\tau$ sama dengan $\tau_{0}$ adalah kurang benar. Oleh sebab itu dengan menggunakan variasi $\tau$ dan $y$ aktual dan diperoleh persamaan baru $d u / d y$, sehingga persamaan Rouse dapat diekspresikan dengan :

$\frac{C}{C_{a}}=\left\{\left(\frac{\sqrt{D}+\sqrt{D-y}}{\sqrt{D}-\sqrt{D-y}}\right)\left(\frac{\sqrt{D}-\sqrt{D-a}}{\sqrt{D}+\sqrt{D-a}}\right)\right\}^{\frac{w_{s}}{u_{s} K}}$

\section{METODOLOGI PENELITIAN}

\section{A. Skema Kerja Penelitian}

Berikut ini adalah skema kerja penelitian yang dilakukan:

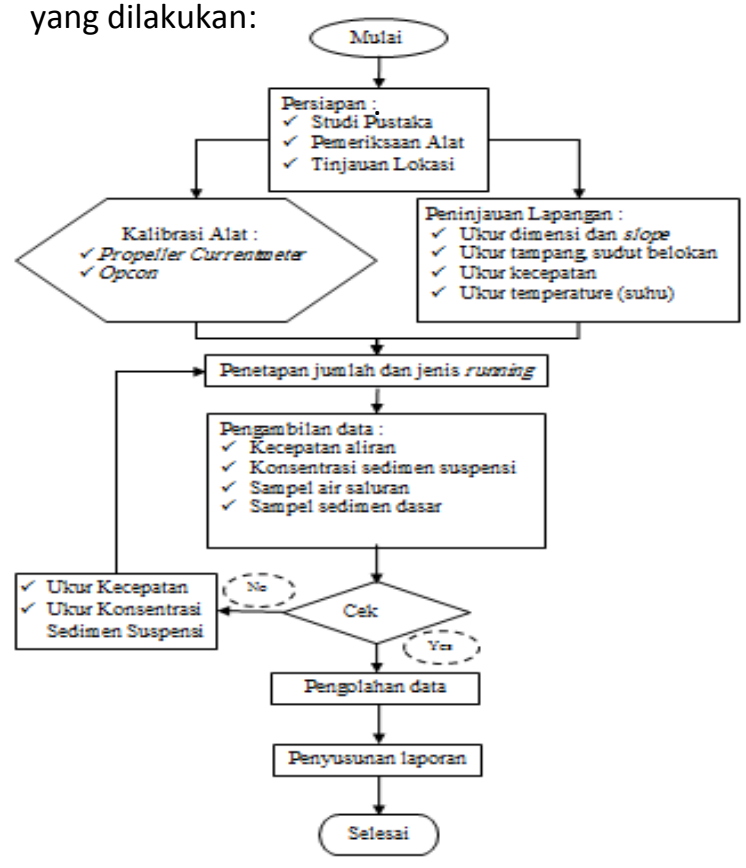

Gambar 7 Skema Penelitian 


\section{B. Diskripsi Umum}

Penelitian ini merupakan pengukuran lapangan yang dilakukan pada belokan Saluran irigasi Mataram dengan tampang persegi serta material dinding saluran yang bervariasi (beton dan pasangan batu). Penelitian ini menggunakan alat ukur kecepatan aliran jenis Propeller Current Meter dan alat ukur konsentrasi sedimen suspensi Opcon. Adapun lokasi penelitian dapat dilihat pada Gambar 8.

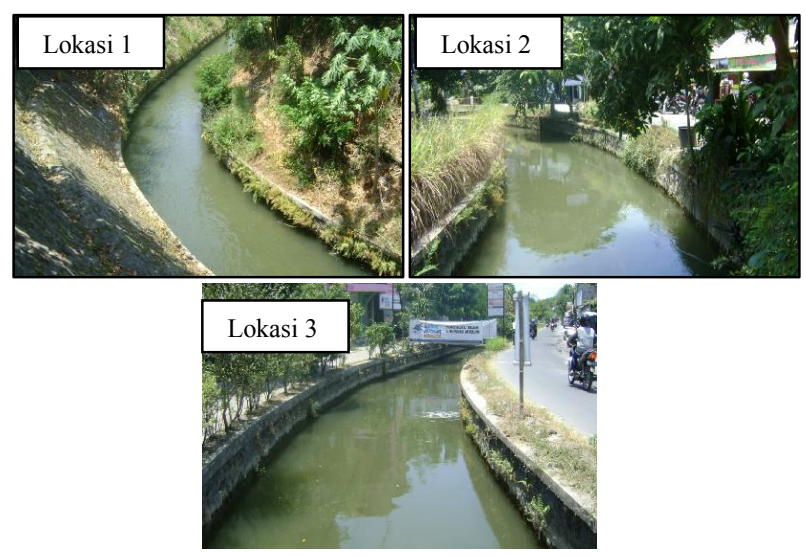

Gambar 8 Lokasi Penelitian (Foto Lapangan)

\section{Prosedur Penelitian}

Parameter yang digunakan untuk pengukuran adalah pengukuran arah vertikal dan transversal, dimana arah vertikal (kedalaman) pada posisi yang berbeda dari tepi ke tepi saluran. Secara praktis, titik-titik tersebut ditentukan berdasarkan pembagian pias-pias tampang. Penentuan jarak pengukuran arah transversal tampang dari tepi ke tepi: $1 / 6,1 / 3 B, 1 / 2 B, 2 / 3 B$, dan $5 / 6 B$.

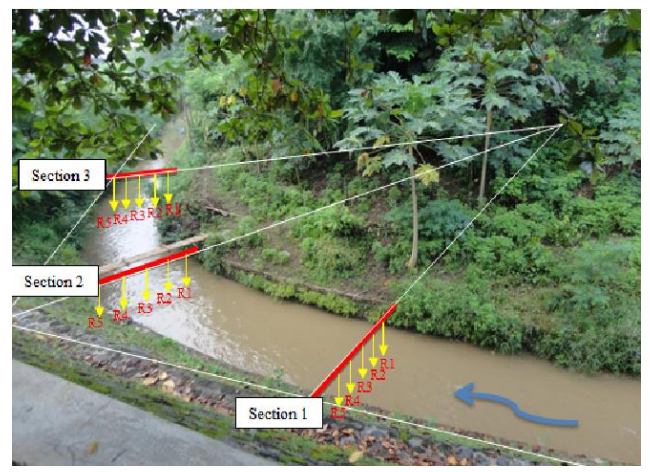

Gambar 9 Skema Titik Pengukuran

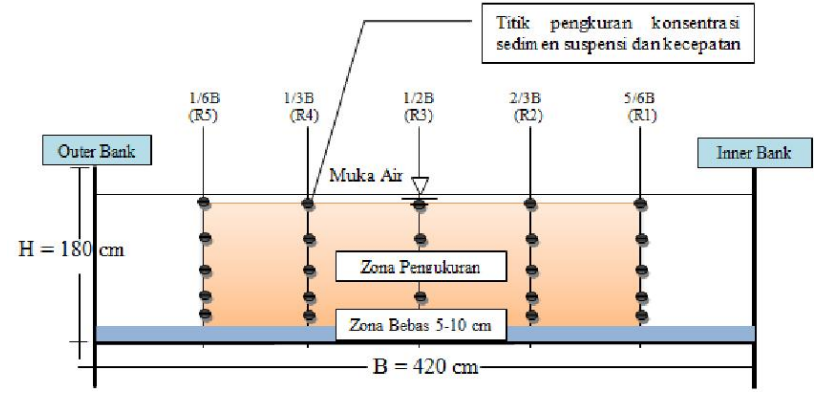

Gambar 10 Sketsa titik pengukuran pada suatu tampang aliran (pengukuran profil konsentrasi sedimen suspensi dan kecepatan)

Pengukuran pada satu tampang yang direncanakan seperti pada Gambar 10 adalah :

1. Cross section yang dipilih yaitu : Sudut belokan $0^{\circ}$ (CO), $27.5^{\circ}$ (C27.5), 55 (C55) pada lokasi pertama dengan sudut belokan $55^{\circ}$, sedangkan pada lokasi kedua dengan sudut belokan $57^{\circ}$ dipilih cross section pada sudut belokan $0^{\circ}$ (C0), $14.25^{\circ}$ (C14.25), 28.5 (C28.5), $42.75^{\circ}$ (C42.75), $57^{\circ}$ (C57) serta pada lokasi ketiga dengan sudut belokan $30^{\circ}$ dipilih cross section pada sudut belokan $0^{\circ}(\mathrm{C} 0), 7,5^{\circ}(\mathrm{C} 7,5), 15^{\circ}$ (C15), 22, $5^{\circ}$ (C22,5), 30 (C30).

2. Saluran terbuka dengan lebar yang bervariasi di setiap section mulai dari lebar 3,96 $\mathrm{m}$ hingga 4,2 $\mathrm{m}$ dan dibagi menjadi 6 pias dengan jarak yang sama setiap pias.

3. Jarak vertikal antara titik pengukuran adalah interval $2,5 \mathrm{~cm}$ untuk bagian bawah dekat dasar $(0,2 \mathrm{H})$ dan sisanya dengan interval $5 \mathrm{~cm}$. Hal ini dilakukan untuk mendapatkan data pengukuran yang lebih banyak untuk inner region, dimana variasi kecepatan terhadap tinggi lebih besar dibandingkan di outer region.

\section{Alat Ukur Utama}

\section{(1) Alat Propeller Current Meter}

Pengukuran distribusi kecepatan dilakukan dengan menggunakan alat Propeller Current Meter yang dapat memberikan hasil pengukuran kecepatan aliran hingga $2,5 \mathrm{~cm} /$ detik dengan batas kedalaman minimum pengukuran kurang lebih $4 \mathrm{~cm}$. Penentuan kecepatan aliran ditentukan oleh putaran baling-baling yang otomatis di kalibrasi oleh alat tersebut dengan menentukan kecepatan alirannya menggunakan persamaan : 
$\mathrm{n}<1,65$ maka, $v=0,0610 . \mathrm{n}+0,0128$

$1,65<\mathrm{n}<3,66$ maka, $v=0,0599 . \mathrm{n}+0,0146$

$n>3,66$ maka, $v=0,0523 . n+0,0425$

dimana, $n$; jumlah rerata putaran baling-baling per detik, v; kecepatan aliran (m/detik).

\section{(2) Alat Opcon}

Alat ukur ini mengukur partikel-partikel lanau (silt) dalam aliran suspensi dengan cara memasukkan alat ke dalam aliran yang akan diukur. Hasil dari pengukuran lalu di kalibrasi. Kalibrasi dilakukan dengan mencari hubungan antara bacaan mesin analog sebagai output dari signal processor yang terletak di atas batang opcon dengan suatu nilai konsentrasi sedimen suspensi yang telah diketahui nilai besarannya.

\section{HASIL PENELITIAN DAN PEMBAHASAN}

\section{A. Parameter Utama Aliran}

Penelitian ini merupakan pengukuran lapangan yang dilakukan pada tiga lokasi yang berupa belokan di sepanjang Saluran Induk Mataram dengan tampang persegi serta material dinding saluran pasangan batu kali. Adapun parameter utama aliran (running) yang diukur adalah pengukuran distribusi kecepatan dan distribusi sedimen suspensi.

Pengkodean running didasarkan pada perbedaan lokasi pengukuran, sudut belokan dan kedalaman titik pengukuran. Untuk lokasi pengukuran lapangan pertama (Field1) dengan sudut belokan $55^{\circ}$ diawali dengan kode F1 sedangkan lokasi pengukuran lapangan kedua (Field2) dengan sudut belokan $57^{\circ}$ dengan kode F2 serta lokasi pengukuran lapangan ketiga (Field3) dengan sudut belokan $30^{\circ}$ dengan kode F3. Pengukuran pada setiap penampang belokan (Section) dilambangkan dengan huruf $\mathbf{S}$ dan jari-jari setiap belokan yang diukur dari inner bank ke outer bank (Resultan) dilambangkan dengan huruf $\mathbf{R}$ serta pengkodean running tiga karakter FSR masingmasing ditambahkan angka untuk menunjukkan jumlah karakter dan urutan pengukuran yang dimulai dari dasar saluran.

Hasil dari pengukuran dan pendataan di lapangan serta analisis akhir terkait kecepatan aliran, konsentrasi sedimen suspensi serta kemiringan saluran dan debit kecepatan diklasifikasikan sebagai parameter utama aliran. Parameter utama aliran ditampilkan secara detail pada tabel 1.

Tabel 1 Parameter Utama Aliran

\begin{tabular}{|c|c|c|c|c|c|c|c|c|c|c|c|c|}
\hline Kode & Radius & So & $B$ & $D$ & $B / D$ & $t$ & $U$ & $u_{t_{c t}}$ & $B r$ & $Q$ & $F r$ & $\bar{c}$ \\
\hline Running & $(-)$ & $(-)$ & (m) & (m) & $\theta$ & ${ }^{\circ} \mathrm{C}$ & m/det & m/det & $10^{5}(-)$ & $\left(\mathrm{m}^{3} / \mathrm{det}\right)$ & $(-)$ & (grllt) \\
\hline \multicolumn{13}{|c|}{ Lokasi 1. Daerah Pogung Rejo (Belokan dengan, $\alpha=55^{\circ}$ dan $\mathrm{R}=58,33 \mathrm{~m}$ ) } \\
\hline F1S1R1 & \multirow{5}{*}{0} & 0.0166 & \multirow{5}{*}{4.15} & 0.67 & 6.19 & 29 & 0.137 & 0.017 & 3.039 & \multirow{5}{*}{0.377} & \multirow{5}{*}{0.05} & 0.152 \\
\hline F1S1R2 & & 0.0166 & & 0.69 & 6.01 & 29 & 0.142 & 0.020 & 2.388 & & & 0.174 \\
\hline F1S1R3 & & 0.0166 & & 0.68 & 6.10 & 29 & 0.146 & 0.021 & 2.075 & & & 0.174 \\
\hline F1S1R4 & & 0.0166 & & 0.65 & 6.38 & 29 & 0.134 & 0.015 & 3.547 & & & 0.206 \\
\hline F1S1R5 & & 0.0166 & & 0.62 & 6.69 & 29 & 0.127 & 0.016 & 3.189 & & & 0.215 \\
\hline F1S2R1 & \multirow{5}{*}{27.5} & 0.0184 & \multirow{5}{*}{4.20} & 0.70 & 6.00 & 30 & 0.143 & 0.016 & 3.560 & \multirow{5}{*}{0.404} & & 0.095 \\
\hline F1152R2 & & 0.0184 & & 0.74 & 5.68 & 30 & 0.149 & 0.020 & 2.707 & & & 0.103 \\
\hline F1122R3 & & 0.0184 & & 0.72 & 5.83 & 30 & 0.154 & 0.022 & 2.229 & & 0.06 & 0.119 \\
\hline F1122R4 & & 0.0184 & & 0.62 & 6.77 & 30 & 0.139 & 0.019 & 2.719 & & & 0.149 \\
\hline F1S2R5 & & 0.0184 & & 0.57 & 7.37 & 30 & 0.133 & 0.019 & 2.937 & & & 0.157 \\
\hline F153R1 & & 0.0202 & & 0.68 & 6.10 & 27 & 0.180 & 0.029 & \begin{tabular}{|l|}
1.553 \\
\end{tabular} & & & 0.335 \\
\hline F153R2 & & 0.0202 & & 0.70 & 5.93 & 27 & 0.173 & 0.025 & 2.163 & & & 0.353 \\
\hline F153R3 & 55 & 0.0202 & 4.15 & 0.69 & 6.01 & 27 & 0.149 & 0.024 & 1.729 & 0.407 & 0.06 & 0.363 \\
\hline F1I33R4 & & 0.0202 & & 0.60 & 6.92 & 27 & 0.127 & 0.020 & 1.758 & & & 0.387 \\
\hline F1S3R5 & & 0.0202 & & 0.62 & 6.69 & 27 & 0.116 & 0.017 & 2.279 & & & 0.403 \\
\hline & & & asi $2 . \mathrm{I}$ & erah $\mathrm{P}_{0}$ & Ing Rej & Belok & dengan, & $=57^{0} \mathrm{~d}$ & $\mathrm{nR}=50$ & & & \\
\hline F2S1R1 & & \begin{tabular}{|l}
0.0010 \\
\end{tabular} & & 0.65 & 6.38 & 28 & 0.097 & 0.018 & \begin{tabular}{|l|l|}
0.055 \\
\end{tabular} & & & 2.499 \\
\hline F2S1R2 & & 0.0010 & & 0.65 & 6.38 & 28 & 0.088 & 0.016 & 0.158 & & & 2.487 \\
\hline F2SIR3 & 0 & 0.0010 & 4.15 & 0.70 & 5.93 & 28 & 0.082 & 0.016 & 0.833 & 0.202 & 0.03 & 2.277 \\
\hline F2SIR4 & & 0.0010 & & 0.55 & 7.55 & 28 & 0.078 & 0.014 & 0.043 & & & 2.045 \\
\hline F2S1R5 & & 0.0010 & & 0.42 & 9.88 & 28 & 0.066 & 0.046 & 2.989 & & & 1.817 \\
\hline$F 252 R 1$ & & 0.0011 & & 0.54 & 7.69 & 29 & 0.086 & 0.049 & 2.836 & & & 3.243 \\
\hline F2S2R2 & & 0.0011 & & 0.64 & 6.48 & 29 & 0.085 & 0.010 & 3.661 & & & 3.224 \\
\hline$F 252 R 3$ & 14.25 & 0.0011 & 4.15 & 0.68 & 6.10 & 29 & 0.099 & 0.014 & 2.056 & 0.263 & 0.04 & 3.239 \\
\hline$F 222 R 4$ & & 0.0011 & & 0.80 & 5.19 & 29 & 0.102 & 0.007 & 6.419 & & & 3.213 \\
\hline F2222R5 & & 0.0011 & & 0.78 & 5.32 & 29 & 0.089 & 0.020 & 0.913 & & & 3.156 \\
\hline F2S3R1 & & 0.0012 & & 0.42 & 10.00 & 30 & 0.082 & 0.022 & 1.389 & & & 1.193 \\
\hline F2S3R2 & & 0.0012 & & 0.60 & 7.00 & 30 & 0.099 & 0.010 & 3.431 & & & 1.174 \\
\hline$F 253 R 3$ & 28.5 & 0.0012 & 4.20 & 0.70 & 6.00 & 30 & 0.099 & 0.012 & 2.640 & 0.265 & 0.04 & 1.198 \\
\hline F2S3R4 & & 0.0012 & & 0.70 & 6.00 & 30 & 0.116 & 0.008 & 7.500 & & & 1.174 \\
\hline F2S3R5 & & 0.0012 & & 0.68 & 6.18 & 30 & 0.113 & 0.008 & 6.909 & & & 1.160 \\
\hline F2S4R1 & & 0.0013 & & 0.48 & 8.65 & 30 & 0.094 & 0.018 & \begin{tabular}{|l|l} 
& 0.044
\end{tabular} & & & 0.830 \\
\hline F2S4AR2 & & 0.0013 & & 0.77 & 5.39 & 30 & 0.114 & 0.008 & 7.414 & & & 0.834 \\
\hline F2S4AR3 & 42.75 & 0.0013 & 4.15 & 0.72 & 5.76 & 30 & 0.114 & 0.024 & 1.286 & 0.432 & 0.05 & 0.815 \\
\hline F2S4R4 & & 0.0013 & & 0.85 & 4.88 & 30 & 0.174 & 0.031 & 0.166 & & & 0.974 \\
\hline F2S4AR5 & & 0.0013 & & 0.90 & 4.61 & 30 & 0.203 & 0.012 & 12.035 & & & 0.905 \\
\hline F255R1 & & 0.0015 & & 0.80 & 5.19 & 29 & 0.107 & 0.007 & 6.707 & & & 0.869 \\
\hline F255R2 & & 0.0015 & & 0.90 & 4.61 & 29 & 0.149 & 0.015 & 3.896 & & & 0.862 \\
\hline F255R3 & 57 & 0.0015 & 4.15 & 0.90 & 4.61 & 29 & 0.180 & 0.009 & |14.109 & 0.610 & 0.05 & 0.864 \\
\hline F255R4 & & 0.0015 & & 0.95 & 4.37 & 29 & 0.185 & 0.007 & \begin{tabular}{|l}
19.033 \\
\end{tabular} & & & 0.853 \\
\hline F255R5 & & 0.0015 & & 1.00 & 4.15 & 29 & 0.186 & 0.010 & \begin{tabular}{|l}
12.867 \\
\end{tabular} & & & 0.869 \\
\hline & & & 13.D & Pog & Dalang & (DE) & n dengar & $\alpha=30$ & $\operatorname{dan} R=6$ & & & \\
\hline F3S1R1 & & \begin{tabular}{|l|l|}
0.0087 \\
\end{tabular} & & 0.65 & 6.32 & 28 & 0.124 & 0.008 & 10.587 & & & 1.748 \\
\hline F3S1R2 & & 0.0087 & & 0.90 & 4.57 & 28 & 0.125 & 0.012 & 4.655 & & & 1.707 \\
\hline FSS1R3 & 0 & 0.0087 & 4.11 & 0.90 & 4.57 & 28 & 0.123 & 0.018 & 1.225 & 0.431 & 0.04 & 1.672 \\
\hline F3S1R4 & & 0.0087 & & 0.90 & 4.57 & 28 & 0.130 & 0.012 & 5.103 & & & 1.668 \\
\hline F3S1R5 & & 0.0087 & & 0.90 & 4.57 & 28 & 0.115 & 0.031 & 1.504 & & & 1.686 \\
\hline F3S2R1 & & 0.0024 & & 0.85 & 4.84 & 30 & 0.102 & 0.008 & 6.740 & & & 2.086 \\
\hline$F 332 R 2$ & & 0.0024 & & 0.90 & 4.57 & 30 & 0.096 & 0.013 & 1.467 & & & 2.209 \\
\hline$F 352 R 3$ & 7.5 & 0.0024 & 4.11 & 0.90 & 4.57 & 30 & 0.103 & 0.011 & 3.022 & 0.357 & 0.03 & 2.351 \\
\hline F3S2R4 & & 0.0024 & & 0.90 & 4.57 & 30 & 0.100 & 0.016 & 0.490 & & & 2.571 \\
\hline F3S2R5 & & \begin{tabular}{|l}
0.0024 \\
\end{tabular} & & 0.82 & 5.01 & 30 & 0.096 & 0.020 & 0.426 & & & 2.678 \\
\hline F3S3R1 & & 0.0036 & & 0.90 & 4.61 & 29 & 0.092 & 0.011 & 2.144 & & & 4.316 \\
\hline F3S3R2 & & 0.0036 & & 1.00 & 4.15 & 29 & 0.097 & 0.011 & 2.814 & & & 4.282 \\
\hline F3S3R3 & 15 & 0.0036 & 4.15 & 0.90 & 4.61 & 29 & 0.087 & 0.011 & 1.217 & 0.320 & 0.03 & 4.012 \\
\hline F3S3R4 & & 0.0036 & & 0.75 & 5.53 & 29 & 0.086 & 0.010 & 2.681 & & & 3.843 \\
\hline F3S3R5 & & 0.0036 & & 0.70 & 5.93 & 29 & 0.091 & 0.002 & 33.646 & & & 3.715 \\
\hline F3S4R1 & & 0.0024 & & 0.95 & 4.33 & 31 & 0.095 & 0.017 & 0.104 & & & 2.880 \\
\hline F3SAR2 & & 0.0024 & & 1.00 & 4.11 & 31 & 0.087 & 0.018 & 1.156 & & & 2.836 \\
\hline F3S4R3 & 22.5 & 0.0024 & 4.11 & 0.85 & 4.84 & 31 & 0.093 & 0.010 & 2.878 & 0.311 & 0.03 & 2.731 \\
\hline F3S4R4 & & 0.0024 & & 0.75 & 5.48 & 31 & 0.087 & 0.008 & 5.213 & & & 2.634 \\
\hline F3S4R5 & & 0.0024 & & 0.70 & 5.87 & 31 & 0.083 & 0.010 & 2.028 & & & 2.543 \\
\hline F355R1 & & 0.0024 & & 0.90 & 4.40 & 28 & 0.110 & 0.002 & 40.208 & & & 1.344 \\
\hline F3S5R2 & & 0.0024 & & 0.90 & 4.40 & 28 & 0.096 & 0.007 & 6.475 & & & 1.288 \\
\hline F355R3 & 30 & 0.0024 & 3.96 & 0.85 & 4.66 & 28 & 0.090 & 0.012 & 1.020 & 0.272 & 0.03 & 1.222 \\
\hline F355R4 & & 0.0024 & & 0.70 & 5.66 & 28 & 0.081 & 0.002 & 26.198 & & & 1.199 \\
\hline F355R5 & & 0.0024 & & 0.45 & 8.80 & 28 & 0.075 & 0.016 & 0.136 & & & 1.109 \\
\hline
\end{tabular}


Keterangan : $Q=$ debit aliran terukur $\left(\mathrm{m}^{3} / \mathrm{det}\right)$; So $=$ kemiringan dasar saluran; $B=$ lebar flume/saluran $(\mathrm{m}) ; D=$ kedalaman aliran $(\mathrm{m})$; $B / D=$ aspect ratio; $t=$ suhu aliran $\left({ }^{\circ} \mathrm{C}\right) ; \alpha=$ Sudut belokan $\left({ }^{\circ}\right) ; R=$ Jari-jari belokan $(\mathrm{m}) ; U=$ kecepatan aliran (m/det); $U^{*}=$ kecepatan gesek aliran ( $\mathrm{m} / \mathrm{det}) ; B r=$ konstanta integrasi dari Log-Low; $F r=U /(g D)^{0.5}$ dan $\bar{C}=$ konsentrasi sedimen suspensi rata-rata tampang (gr/liter).

\section{B. Distribusi Kecepatan}

Dari analisis diperoleh data utama yaitu kecepatan aliran arah transversal (melintang aliran), $v$ dan kecepatan arah vertikal, $w$.

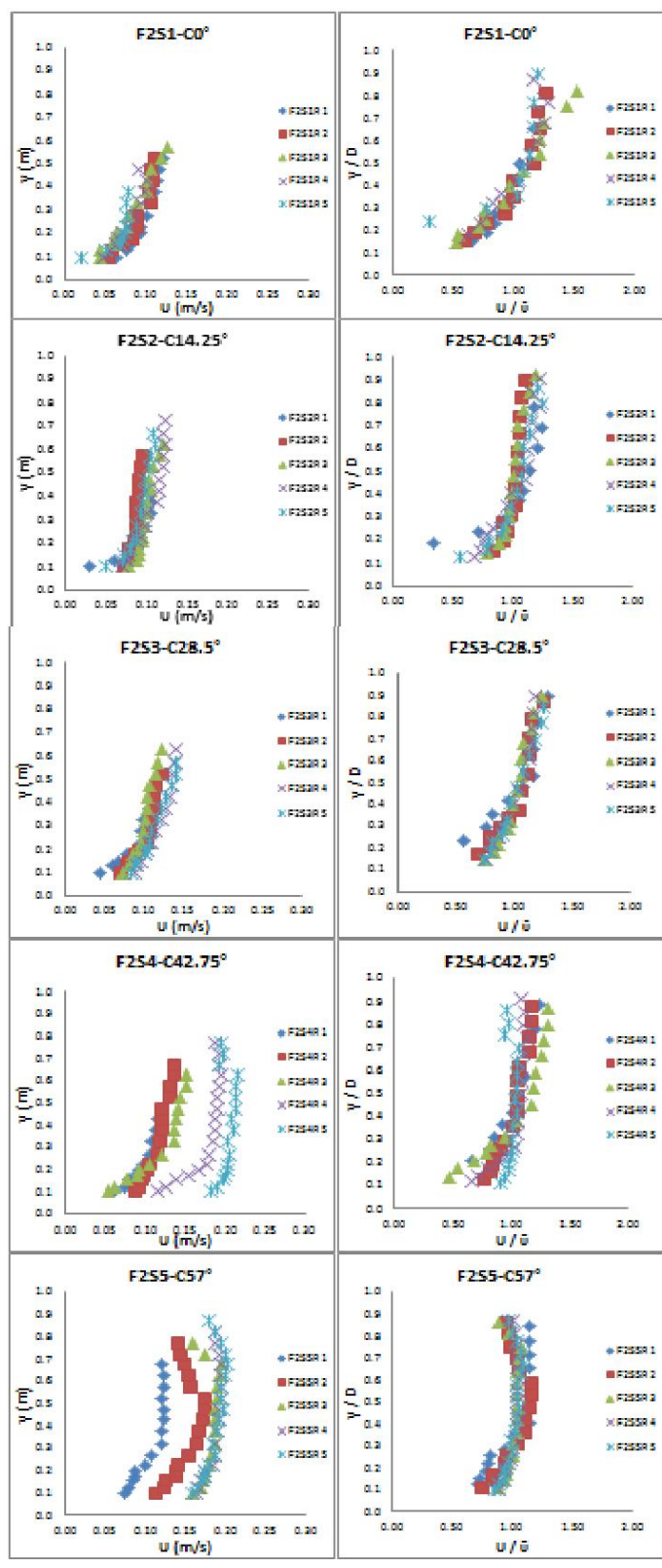

Gambar 11 Profil distribusi kecepatan berdimensi dan tak berdimensi pada section $\mathrm{CO}^{\circ}, \mathrm{C} 14.25^{\circ}, \mathrm{C} 28.5^{\circ}, \mathrm{C} 42.75^{\circ}, \mathrm{C} 57^{\circ}$ di belokan ke-2 dengan $\alpha=57^{\circ}$

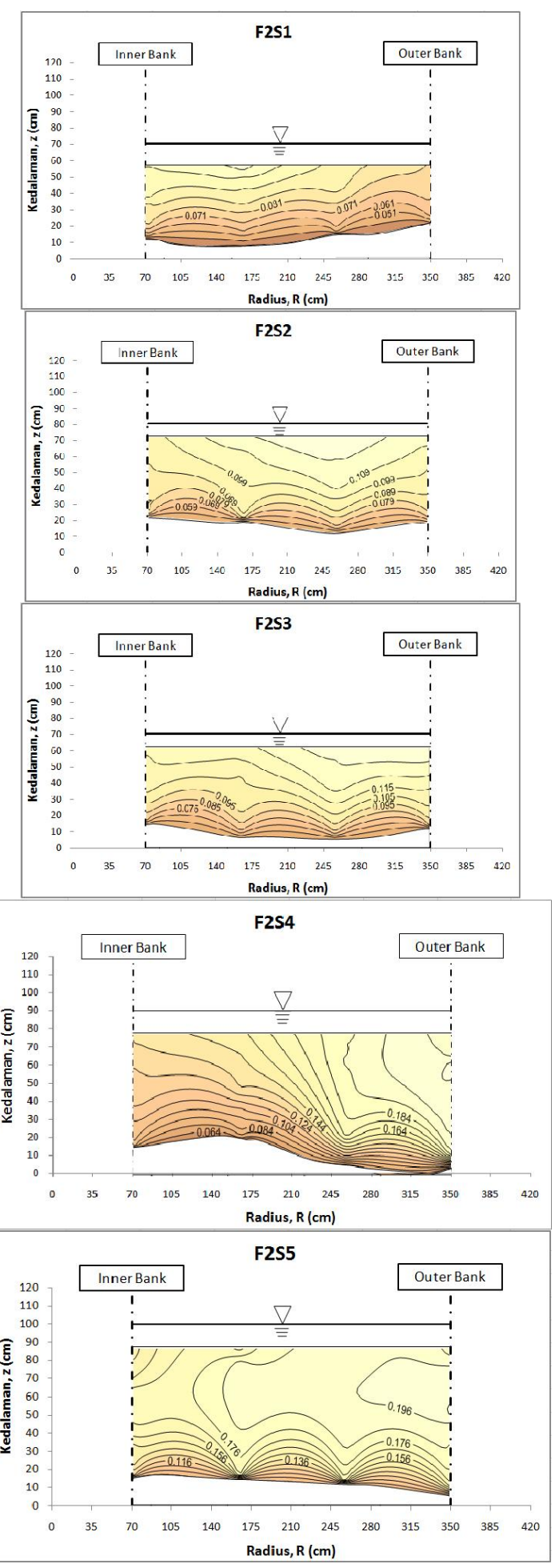

Gambar 12 Kontur kecepatan pada tiap section dibelokan ke-2 dengan $\alpha=57^{\circ}$ 
Dari Gambar 11 dan 12 dapat dijelaskan bahwa Secara umum, analisis distribusi kecepatan hasil pengukuran lapangan menunjukkan bahwa trend distribusi kecepatan minimum terjadi di dekat dasar dan bertambah besar ke arah permukaan aliran. Kecepatan aliran mengalami percepatan dan perlambatan ketika melalui belokan, dimana kecepatan aliran meningkat di sisi dalam belokan (inner bank) ketika melewati awal belokan dan kecepatan menurun saat melewati akhir belokan, sebaliknya kecepatan aliran menurun di sisi luar belokan (outer bank) ketika melewati awal belokan dan mengalami peningkatan di sisi dalam belokan (inner bank) saat melewati akhir belokan.

Untuk analisis kelengkungan muka air pada belokan didekati dengan persamaan dari Kozeny (1953) dalam (Graf dan Altinakar, 1998). Dari metode tersebut diperoleh persamaan pendekatan untuk analisis lengkung muka air melintang adalah $\Delta z_{2}=\frac{U^{2}}{2 g}\left(1-\frac{r_{o}}{r_{2}}\right)$ dan $\Delta z_{1}=\frac{U^{2}}{2 g}\left(\frac{r_{o}}{r_{1}}-1\right)$ dengan kondisi fixed bed. Hasil analisis yang dilakukan pada titik running F1S2 adalah diperoleh $\Delta z_{1}=4,2 \times 10^{-5}$ dan $\Delta z_{2}=-6,2 \times 10^{-5}$, ini menunjukkan bahwa terjadi erosion pada sisi luar belokan (outer bank) dan terjadi deposition pada sisi dalam belokan (inner bank). Adapun contoh analisis kelengkungan muka air pada belokan dapat dilihat pada gambar 13 contoh titik running F1S2.

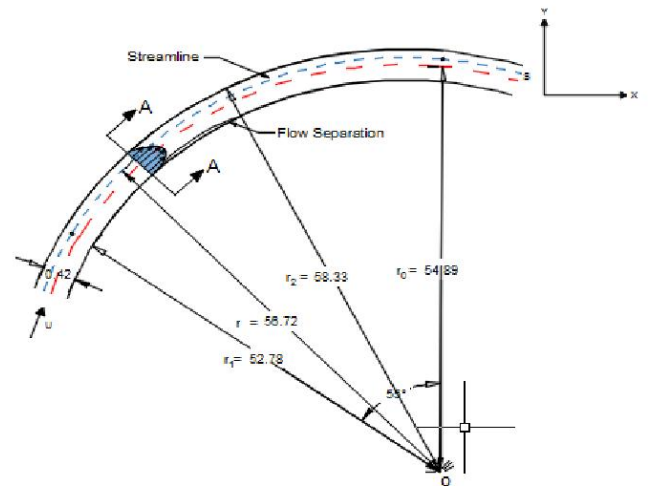

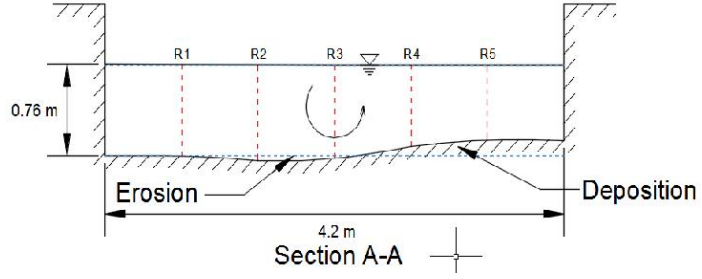

Gambar 13 Skema Aliran pada Belokan

\section{Distribusi Konsentrasi Sedimen Suspensi}

Dari hasil pengukuran sedimen suspensi, lalu dianalisis sehingga diperoleh data utama yaitu konsentrasi sedimen suspensi.

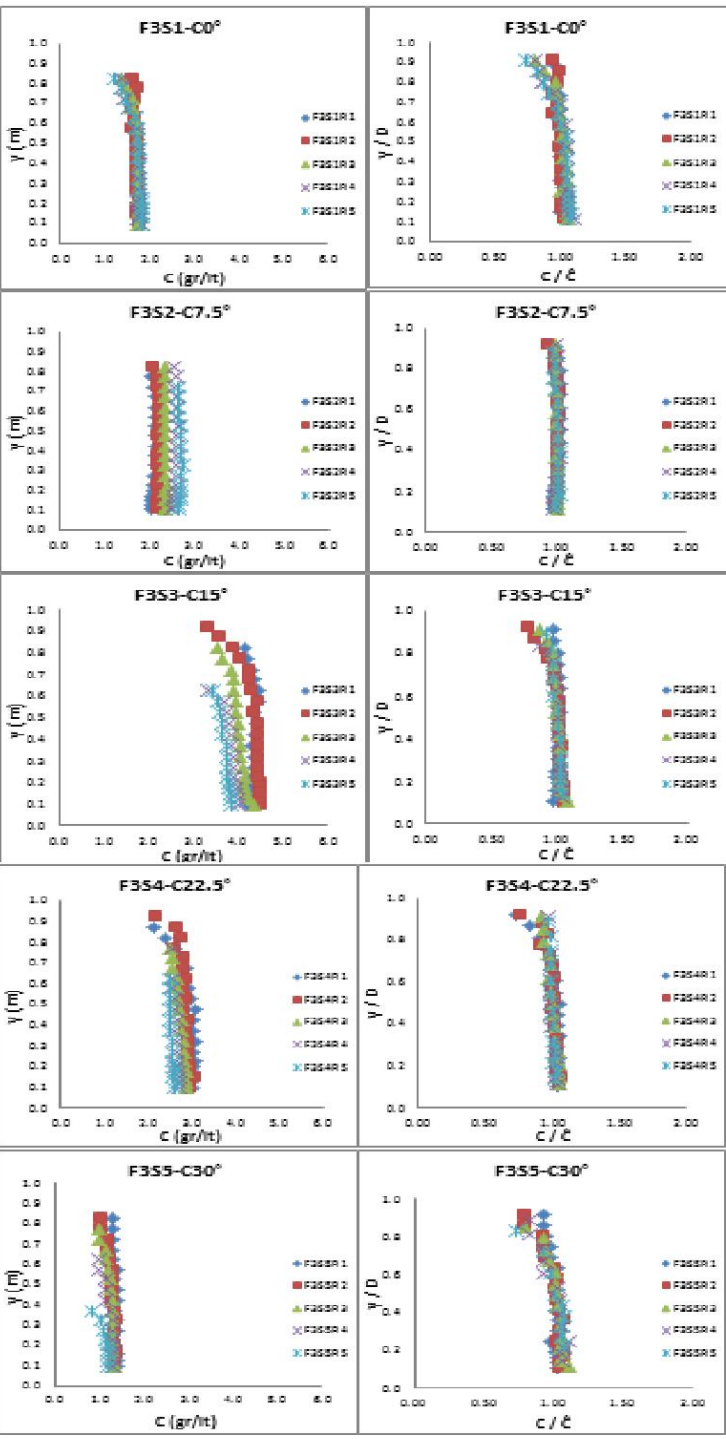

Gambar 14 Profil distribusi konsentrasi sedimen suspensi berdimensi dan tak berdimensi pada section $\mathrm{C}^{\circ}, \mathrm{C} 14.25^{\circ}, \mathrm{C} 28.5^{\circ}$, $\mathrm{C} 42.75^{\circ}, \mathrm{C} 57^{\circ}$ di belokan ke- 2 dengan $\alpha=57^{\circ}$ 


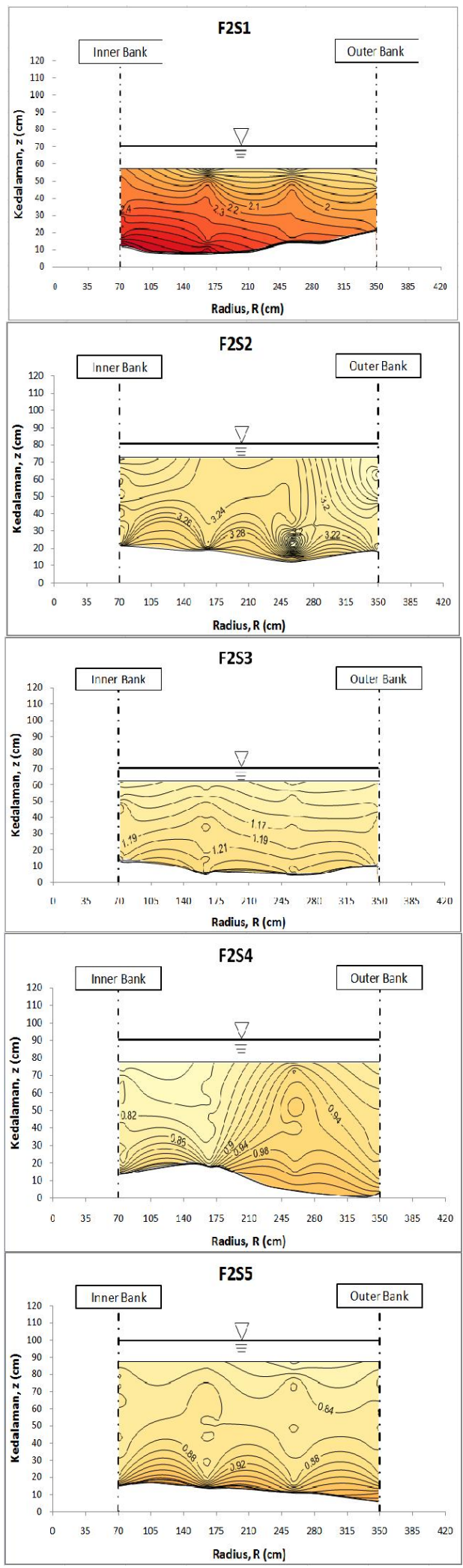

Gambar 15 Kontur konsentrasi sedimen suspensi pada tiap section dibelokkan ke-2 dengan $\alpha=57^{\circ}$
Dari Gambar 14 dan 15 dapat dijelaskan bahwa Secara umum, distribusi konsentrasi sedimen suspensi hasil pengukuran lapangan mulai dari belokan dengan sudut, $\alpha=30^{\circ}, \alpha=55^{\circ}$ hingga $\alpha=57^{\circ}$ menunjukkan bentuk yang hampir sama untuk seluruh tampang, yaitu konsentrasi sedimen suspensi meningkat ke arah dasar saluran dan mengalami penurunan ke arah permukaan air dengan trend distribusinya semakin tegak dengan nilai yang semakin seragam ke arah permukaan air. Pada arah transversal, konsentrasi sedimen suspensi cenderung meningkat ke arah sisi dalam belokan (inner bank) ketika melewati awal belokan, lalu mengecil ke arah sisi dalam belokan (inner bank) saat melewati pertengahan belokan dan kembali meningkat ke arah sisi dalam belokan (inner bank) saat melewati akhir belokan yang mengakibatkan terjadinya deposition di sisi dalam belokan (inner bank) dan terjadinya erosion di sisi luar belokan (outer bank).

\section{Prediksi Distribusi Sedimen Suspensi Dengan Persamaan di Literatur}

Sebagaimana disampaikan pada bab kajian pustaka, di literatur banyak dijumpai persamaan-persamaan teoritis/ semi teoritis yang dapat dipergunakan untuk menentukan distribusi konsentrasi sedimen suspensi. Diantara beberapa persamaan tersebut, persamaan yang paling populer adalah persamaan Rouse dan persamaan TanakaSugimoto. Oleh karena itu, persamaan Rouse dan Tanaka-Sugimoto digunakan sebagai dasar untuk mengkaji dan membandingkan data distribusi konsentrasi sedimen suspensi yang digunakan dalam tulisan ini dengan persamaanpersamaan di literatur.

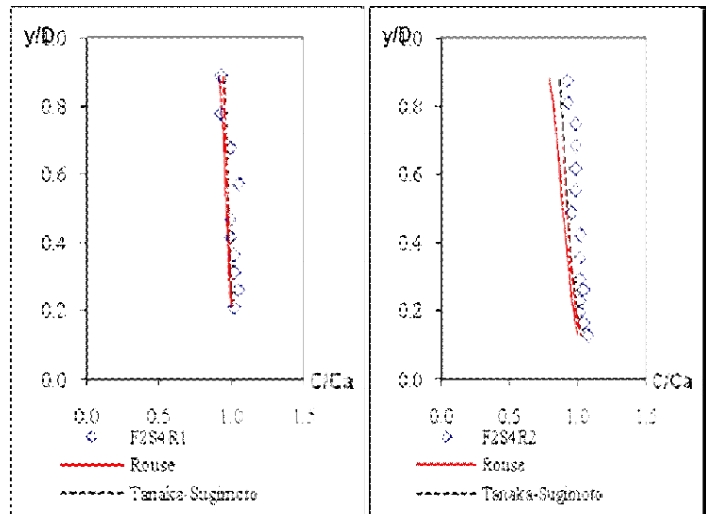



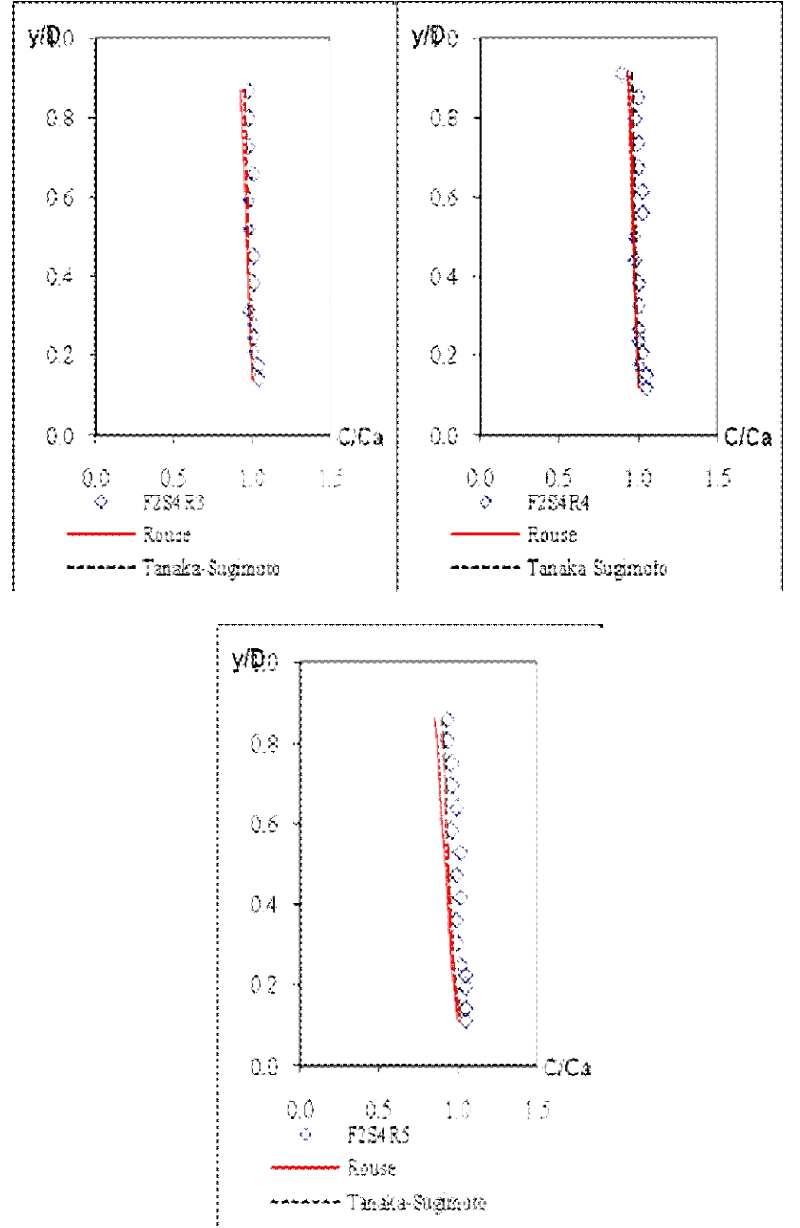

Gambar 16 Distribusi Konsentrasi sedimen suspensi hasil pengukuran dibandingkan dengan persamaan Rouse dan Tanaka-

Sugimoto untuk aliran pada belokan dengan $\alpha=57^{\circ}$

Dari Gambar 16 menunjukkan bahwa secara umum, analisis distribusi konsentrasi sedimen suspensi hasil pengukuran lapangan yang dibandingkan dengan analisis dari persamaan Rouse dan persamaan TanakaSugimoto menunjukkan bahwa cukup dapat memprediksi data pengukuran distribusi sedimen suspensi pada belokan, meskipun sudut dan jari-jari belokan berbeda-beda. Mulai dari belokan dengan sudut, $\alpha=30^{\circ}, \alpha=55^{\circ}$ hingga $\alpha=57^{\circ}$ dimana data hasil pengukuran distribusi sedimen suspensi nilainya mendekati data hasil analisis Rouse dan Tanaka-Sugimoto. Adapun hasil analisis Tanaka-Sugimoto bisa memberikan hasil lebih baik dari analisis Rouse.

\section{PENUTUP}

Dari analisis yang dilakukan, maka dapat disimpulkan bahwa:

1. Analisis kecepatan hasil pengukuran lapangan mulai dari belokan dengan sudut, $\alpha=30^{\circ}, \alpha=55^{\circ}$ hingga $\alpha=57^{\circ}$ menunjukkan bahwa trend distribusi kecepatan minimum terjadi di dekat dasar dan bertambah besar ke arah permukaan aliran. Kecepatan aliran mengalami percepatan dan perlambatan ketika melalui belokan, dimana kecepatan aliran meningkat di sisi dalam belokan (inner bank) ketika melewati awal belokan dan kecepatan menurun saat melewati akhir belokan, sebaliknya kecepatan aliran menurun di sisi luar belokan (outer bank) ketika melewati awal belokan dan mengalami peningkatan di sisi dalam belokan (inner bank) saat melewati akhir belokan.

2. Analisis konsentrasi sedimen suspensi hasil pengukuran lapangan dengan sudut belokan yang bervariasi menunjukkan bahwa trend distribusi konsentrasi sedimen suspensi meningkat ke arah dasar saluran dan mengalami penurunan ke arah permukaan air dengan trend distribusinya semakin tegak dengan nilai yang semakin seragam ke arah permukaan air. Pada arah transversal, konsentrasi sedimen suspensi cenderung meningkat ke arah sisi dalam belokan (inner bank) ketika melewati awal belokan, lalu menurun ke arah sisi dalam belokan saat melewati pertengahan belokan dan kembali meningkat ke arah sisi dalam belokan saat melewati akhir belokan yang mengakibatkan terjadinya deposition di sisi dalam belokan (inner bank) dan erosion di sisi luar belokan (outer bank) pada dasar saluran.

3. Analisis distribusi konsentrasi sedimen suspensi hasil pengukuran lapangan yang dibandingkan dengan analisis dari persamaan Rouse dan persamaan TanakaSugimoto menunjukkan bahwa cukup dapat memprediksi data pengukuran distribusi sedimen suspensi pada belokan, meskipun sudut dan jari-jari belokan bervariasi. Data hasil pengukuran sedimen suspense nilainya mendekati data hasil analisis Rouse dan Tanaka-Sugimoto. Adapun hasil analisis Tanaka-Sugimoto bisa memberikan hasil 
yang lebih baik dari analisis Rouse pada belokan saluran terbuka.

Adapun saran dari kesimpulan di atas bahwa untuk penelitian lebih lanjut mengenai topik bahasan yang serupa terutama di dalam pengambilan data pembacaan sangat perlu dilakukan pembagian grid yang lebih rapat dan teratur (jarak antar grid yang lebih seragam) terutama pada wilayah dekat dasar saluran (inner region) yang dimulai dari titik referensi $0,2 d$ agar diperoleh data lebih banyak serta data yang lebih seragam dan teratur.

\section{DAFTAR PUSTAKA}

Blanckaert, K. and Graf, W. H. 2001. Mean Flow and Turbulence in Open Channel Bend. Journal of Hydraulic Engineering. Vol. 127: 835 - 847.

Garde, R. J., and Ranga Raju, K. G., 1977, Mechanics of Sediment Transportation and Alluvial Streams Problems, Wiley Eastern Limited, New Delhi.

Graf, W.H. and M.S. Altinakar, 1998, FLUVIAL HYDRAULICS - Flow and Transport Processes in Channels of simple Geometry, Presses polytechniques romandes, Lausanne, $\mathrm{CH}$., John Wiley \& Sons Ltd, West Sussex, England.

Kironoto, B.A. 1993, Turbulence Characteristics of Uniformand Non-Uniform Rough Open Channel Flow, Doctoral Disertation. Ecole Plytechnique Federale de lau (EPFL), Switzerland.

Kironoto, B.A., Lutjito. and Nugraha, D.H., 2002. Karakteristik Aliran tidak Seragam Dengan Sedimen Suspensi Pada Saluran Terbuka. Journal Dinamika Teknik Sipil, Penelitian Pasca Sarjana, Universitas Gadjah Mada, Yogyakarta.

Kironoto, B.A., Andoyono, T., Yustiana, F, dan Muharis, C., 2004, Kajian Metode Pengambilan Sampel Sedimen Suspensi Sebagai Dasar Penentuan Debit Sedimen Pada Saluran Terbuka, Penelitian Hibah Bersaing, XII/1-Th. Anggaran 2004, Lembaga Penelitian, Universitas Gadjah Mada, Yogyakarta.

Lutjito, 2002, Sedimen Suspensi Pada Kondisi Aliran Diperlambat Dalam Saluran Terbuka, Tesis S-2 Program Pascasarjana Jurusan Teknik Sipil dan
Lingkungan, Fakultas Teknik, Universitas Gadjah Mada, Yogyakarta.

Purnama, A, 2015. Konsentrasi Sedimen Suspensi pada Belokan $57^{\circ}$ Saluran Terbuka, Jurnal Unsa Progress. Vol.1, No.3, Oktober, Universitas Samawa, Sumbawa Besar.

Purnama, A. and Nuraini, E, 2016. Analisis Distribusi Kecepatan dan Sedimen pada Tikungan $55^{\circ}$ Saluran Terbuka Tampang Segi Empat, Jurnal Unsa Progress. Vol.21, No.3, Juli, Universitas Samawa, Sumbawa Besar.

Rozovskii, I. L. 1957. Flow of Water in Bends of Open Channels. Israel Programme of Scientific Translation, Jerussalem.

Sangging, P.Y.B., 2013, Karakteristika Distribusi Tegangan Geser Pada Saluran Menikung Dengan Dasar Rata TakBergerak, Tesis S-2 Program Pascasarjana Jurusan Teknik Sipil dan Lingkungan, Fakultas Teknik, Universitas Gadjah Mada, Yogyakarta

Vanoni, V. A., 1977, Sedimentation Engineering, ASCE, New York.

Yang, C T, 1996, Sediment Transport Theory and Practice, The McGraw-Hill Companies, Inc., New York.

Yulistiyanto, B., 1997, Flow Around a Cylinder Installed in a Fixed-Bed Open Channel. Docteur es Sciences Techniques These, Ecole Polytechnique Federale de Lausanne, Lausanne.

Zainuddin, M., dan Kironoto, BA, 2003, "Distribusi Sedimen Suspensi Pada Aliran Seragam Dengan dan Tanpa Angkutan Sedimen Dasar", Journal Teknosains, Jilid 16, No.1, Januari, Berkala Penelitian Pascasarjana, Universitas Gadjah Mada, Yogyakarta. 